Article

\title{
Swimming Performance of Four Carps on the Yangtze River for Fish Passage Design
}

\author{
Junjun Tan ${ }^{1}$, Hong $\mathrm{Li}^{1}$, Wentao Guo ${ }^{2}$, Honglin Tan ${ }^{1}$, Senfan Ke ${ }^{1}$, Jibao Wang ${ }^{1}$ and Xiaotao Shi ${ }^{1, *}$ \\ 1 Hubei International Science and Technology Cooperation Base of Fish Passage, China Three Gorges \\ University, Yichang 443002, China; tanjunjun@ctgu.edu.cn (J.T.); lihong20210124@163.com (H.L.); \\ tan1642709374@163.com (H.T.); 15926989126@163.com (S.K.); wjbtina@ctgu.edu.cn (J.W.) \\ 2 Chinese Sturgeon Research Institute, China Three Gorges Corporation, Yichang 443100, China; \\ realgwt2008@163.com \\ * Correspondence: xbbjb@ctgu.edu.cn
}

Citation: Tan, J.; Li, H.; Guo, W.; Tan, H.; Ke, S.; Wang, J.; Shi, X. Swimming Performance of Four Carps on the Yangtze River for Fish Passage Design. Sustainability 2021, 13, 1575. https://doi.org/10.3390/ su13031575

Academic Editor: Gioele Capillo

Received: 5 January 2021

Accepted: 28 January 2021

Published: 2 February 2021

Publisher's Note: MDPI stays neutral with regard to jurisdictional claims in published maps and institutional affiliations.

Copyright: (c) 2021 by the authors. Licensee MDPI, Basel, Switzerland. This article is an open access article distributed under the terms and conditions of the Creative Commons Attribution (CC BY) license (https:// creativecommons.org/licenses/by/ $4.0 /)$.

\begin{abstract}
Anthropogenic engineered structures alter the local ecological connectivity of river and survival habitat of native fishes. The swimming performance is critical for establishing fish passage or fish habitat. This study evaluated the swimming performance of four carps (black carp, grass carp, silver carp and bighead carp) with smaller body lengths $(1.0-9.0 \mathrm{~cm})$ in a swimming flume. The results showed that the critical and burst swimming speed $(\mathrm{m} / \mathrm{s})$ of the four carps increased with the increased body length, and the relative (critical and burst) swimming speed (the critical and burst swimming speed divided by the body length, BL/s) decreases with body length. The critical and burst swimming speed of each species at two individual length groups $(1.0-5.0 \mathrm{~cm}, 5.1-9.0 \mathrm{~cm})$ was significantly different $(p<0.05)$, and the water velocities in fish passage should be less than the fish burst swimming speed. The results further provided the swimming performance data of juvenile carps and provided technical reference for the construction of fish passage and the restoration of ecological habitat.
\end{abstract}

Keywords: four carps; swimming performance; body length; fish passage

\section{Introduction}

Black carp (Mylopharyngodon piceus), grass carp (Ctenopharyngodon idella), silver carp (Hypophthalmichthys molitrix) and bighead carp (Hypophthalmichthys nobilis) (namely four carps) are recognized as the most commercially important freshwater fish species $[1,2]$. They are endemic to eastern China, and have been introduced worldwide as commercially important fish. They are typical potamodromous fish. In the Yangtze River basin, for example, in the annual spawning season (spring), the fish clusters migrate into the river to spawn. After spawning, the eggs and larvae drift downstream and juveniles move to the rearing habitat in the floodplain lakes [3].

During the past several decades, the four carps have rapidly declined due to human activities such as overfishing, building dams, channel and other hydraulic structures. The anthropogenic hydraulic structures severed river connectivity, altered the habitat, and obstructed the migration and spawning of carps. As a result, the abundance of these carps has dropped rapidly since the 1980s [2]. Remedies may include fish passage for upstream migration, habitat restoration, fish passage for downstream migration or bypass channels, etc. [4,5]. Juvenile carps usually migrate by utilizing their swimming ability [6]. Therefore, testing juvenile carps' swimming performance can provide data for establishing fish passage and ecological habitat, and can be used in fisheries management and ecophysiological studies [7-10].

Some studies investigated the oxygen consumption rate of four carps, the swimming ability and swimming behavior of grass carp (10-15 cm) [11], bighead carp (12.5-27.5 cm) [12], silver carp $(7.3-16.8 \mathrm{~cm})$ [13]. Because the juvenilecarps will migrate into Poyang Lake, the 
swimming ability of juvenile carps with smaller body lengths $(1-10 \mathrm{~cm})$ therefore required further study.

The primary objective of this study was to provide the swimming performances of four juvenile carps by measuring critical swimming speed $\left(U_{c r i t}\right)$ and burst speed $\left(U_{\text {burst }}\right)$. The effect of body length on swimming performance was investigated. The collected data were then used to obtain the suitable velocity recommendations for habitat ecological restoration and establishing fish passage.

\section{Material and Methods}

\subsection{Experimental Setup and Fish}

All experimental fish (as shown in Table 1) were obtained from Qingjiang, Yidu City, China. They were transported into aerated bags and then sent to Three Gorges University, Yichang, China $\left(30^{\circ} 43^{\prime} 47.38^{\prime \prime} \mathrm{N}, 111^{\circ} 18^{\prime} 26.04^{\prime \prime} \mathrm{E}\right)$. All fish were housed in a $1.5 \mathrm{~m}$ (diameter) $\times 0.3 \mathrm{~m}($ height $) \times 0.2 \mathrm{~m}($ depth of water) aerated fish tank. Constant recirculation water exchange was used to stabilize water temperature (mean $\pm \mathrm{SD}=23 \pm 0.8^{\circ} \mathrm{C}$ ). To recover from handling stress, fish were housed in the tanks for at least 5 days. The fish were fed on pond sticks (Tetra $\mathrm{GmbH}$ ) until 24h prior to experimentation. Before each trial, the total body length $(\mathrm{BL})(\mathrm{cm})$ was measured by vernier caliper and the weight $(\mathrm{g})$ of the fish was measured by electronic scale (Table 1). The maximum cross-sectional area of tested fish was less than $10 \%$ of the cross-sectional area of the swim chamber, thus eliminating the need to adjust for blocking effect [14].

Table 1. Parameters of fish species in experiment.

\begin{tabular}{cccccc}
\hline $\begin{array}{c}\text { Swimming } \\
\text { Index }\end{array}$ & Fish Species & $\begin{array}{c}\text { No. of } \\
\text { Tested Fish }\end{array}$ & Weight $\mathbf{( g )}$ & $\begin{array}{c}\text { Body Length } \\
\mathbf{( c m )}\end{array}$ & $\begin{array}{c}\text { Total Length } \\
\mathbf{( c m )}\end{array}$ \\
\hline Burst & BL & 32 & $4.72 \pm 0.13$ & $6.63 \pm 1.12$ & $7.17 \pm 1.31$ \\
swimming & GR & 36 & $5.25 \pm 0.20$ & $7.23 \pm 1.05$ & $7.86 \pm 1.37$ \\
speed & SI & 39 & $5.46 \pm 0.15$ & $7.36 \pm 1.12$ & $7.97 \pm 1.33$ \\
& BI & 46 & $6.30 \pm 0.21$ & $7.52 \pm 0.91$ & $8.12 \pm 1.30$ \\
\hline Critical & BL & 41 & $4.53 \pm 0.25$ & $6.80 \pm 1.04$ & $7.46 \pm 1.23$ \\
swimming & GR & 36 & $5.57 \pm 0.21$ & $6.52 \pm 1.17$ & $7.55 \pm 1.32$ \\
speed & SI & 32 & $5.73 \pm 0.19$ & $6.98 \pm 1.06$ & $7.82 \pm 1.22$ \\
& BI & 46 & $6.23 \pm 0.23$ & $7.51 \pm 1.14$ & $8.42 \pm 1.16$ \\
\hline
\end{tabular}

Notes: BL represents Black carp (Mylopharyngodon piceus), GR represents Grass carp (Ctenopharyngodon idella), SI represents silver carp (Hypophthalmichthys molitrix), BI represents Bighead carp(Hypophthalmichthys nobilis).

Swimming performances were measured in a recirculating swimming flume (Figure 1) with a rectangular swim chamber from Loligo System (Loligo system SW10150, Viborg, Denmark). Water velocity within the flumes was controlled by an electric motor. A calibration curve between the motor setting and average cross-sectional velocity of swim chamber was formed to set water velocity within the swim chamber. The dissolved oxygen and temperature in the respirometer were monitored with a multiparameter probe (YSI DO200A). Constant recirculation water exchange was employed to stabilize water temperature (mean $\pm \mathrm{SD}=23.0 \pm 0.8^{\circ} \mathrm{C}$ ), and dissolved oxygen was about $6.0 \mathrm{mg} \cdot \mathrm{L}^{-1}$.

The experiment process of the fish was recorded by a video recording system, including a digital video recorder (DS-7808N-K1/C, Hikvision Corporation, Hangzhou, China) and two 25fps video cameras (DC-2CD3T35D.I3, Hikvision Corporation), which were placed $2 \mathrm{~m}$ above the water surface to monitor the test fish, respectively. After the trial, the fish were removed from the swim chamber, measured, and weighed before being returned to the fish tank. 


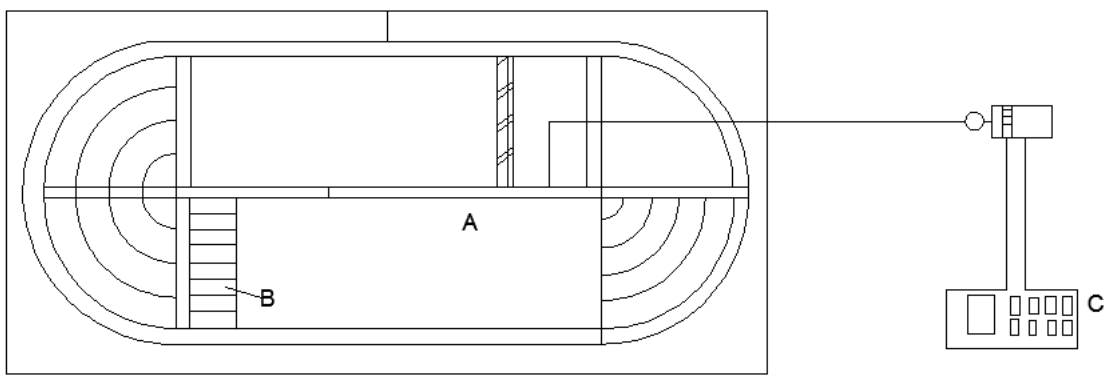

Figure 1. Planform of the experimental swimming flume (A: swimming chamber; B: honeycomb matrix for flow calibration; $\mathrm{C}$ : Variable frequency electric motor).

\subsection{Test Methods}

For a more complete characterization of swimming ability, stepped velocity tests were performed to measure critical swimming speed and burst swimming speed [7].

The water velocity was initially set at $1 \mathrm{BL} / \mathrm{s}$, and increased by specified time intervals $(\Delta t)$ until the fish ceased swimming for $5 \mathrm{~s}$ and was considered exhausted $[7,15,16] . U_{c r i t}$ and $U_{\text {burst }}$ were identified by conducting increasing velocity tests and were calculated using the formula described by Brett (1964), as follows:

$$
U_{\mathrm{i}}=U_{p}+(t / \Delta t) \times \Delta U
$$

where $U_{i}$ is fish swimming speed, $U_{p}(\mathrm{BL} / \mathrm{s})$ is the maximal velocity when suffering water $(\mathrm{m} / \mathrm{s}), \Delta U$ is the water-velocity increment $(1 \mathrm{BL} / \mathrm{s}), t(\mathrm{~s})$ is the time elapsed at fatigue velocity (min), and $\Delta t$ is the time step ( $\Delta t$ is $20 \mathrm{~min}$ for $U_{\text {crit }}$ and $20 \mathrm{~s}$ for $U_{\text {burst }}$ ).

The relative (critical and burst) swimming speed $U_{\text {Crit }}$ and $U_{\text {burst }}$ is equal to the critical and burst swimming speed divided by the body length (BL/s).

Because $U_{i}$ varies significantly among individuals, it is usual to characterize the swimming capacity of a species through the mean critical velocity (e.g., Castro et al. 2010) [17]:

$$
\bar{U}=\frac{1}{n} \sum_{i}^{n} U_{\mathrm{i}}
$$

where $n$ is the total number of individuals.

For a standardization of the swimming capacity according to the body length, Smit et al. (1971) [18] and Laborde et al. (2016) [19] proposed the standard critical velocity:

$$
U^{*}=\frac{1}{n} \sqrt{\frac{1}{n} \sum_{i}^{n} L_{i} \frac{U_{i}{ }^{2}}{L_{i}}}
$$

where $L_{i}$ is the total body length of the $i$ - fish, $U^{*}$ allows comparison between species.

\subsection{Statistical Analysis}

Data were presented as the means \pm standard deviation (S.D.). Analyses were performed using data collected in all experiments based on the video observations and monitoring. Linear regression analysis was used to describe the relationships between $U\left(U_{c r i t}\right.$, $\left.U_{\text {burst }}\right)$ and continuous body length (BL). The relative critical and burst swimming speeds of four fish species were analyzed by using the nonparametric test of multiple independent samples (Kruskal-Wallis), and one-way ANOVA was used to analyze the swimming ability difference fortwo categories of lengths of fish. The statistical procedure was performed using IBM SPSS Statistics 22.0 software. Statistical significance was set at $P<0.05$. 


\section{Results}

\subsection{Critical Swimming Speed}

The results showed that the critical swimming speeds of four carps were ranging from 0.21 to $0.85 \mathrm{~m} / \mathrm{s}$ for black carp $(2-8 \mathrm{~cm})$, from 0.12 to $0.86 \mathrm{~m} / \mathrm{s}$ for grass carp $(2-8 \mathrm{~cm})$, from 0.10 to $0.94 \mathrm{~m} / \mathrm{s}$ for silver carp $(2-9 \mathrm{~cm})$, and from 0.27 to $0.66 \mathrm{~m} / \mathrm{s}$ for bighead carp (1-9 cm), respectively (Figure 2). The critical swimming speed for different body lengths of test fish is shown in Table 2. Linear regression test on the critical swimming speed of four carps with different lengths is shown in Table 3, and one-way ANOVA analysis for the critical swimming speed of the four carps at two categories of lengths $(1-5 \mathrm{~cm}, 5-9 \mathrm{~cm})$ is shown in Table 4.

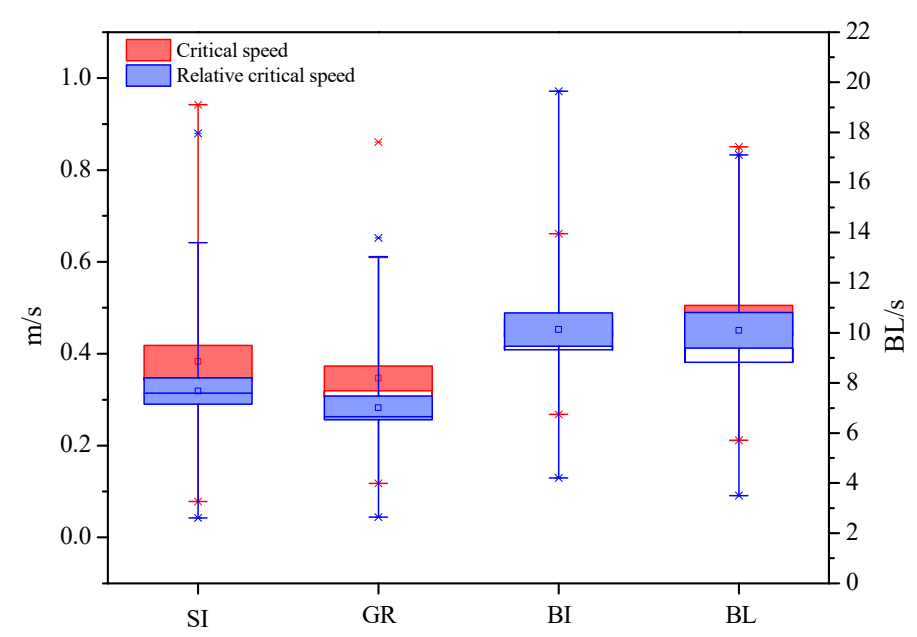

(a)

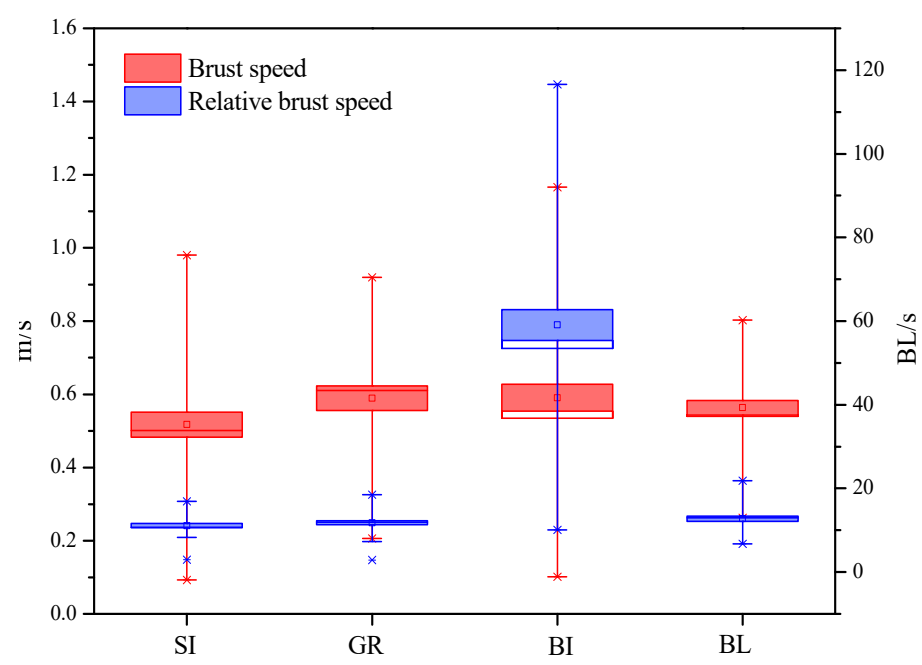

(b)

Figure 2. Test results of fish swimming performance showed by box plot including: (a) critical speed; (b) bursting speed for all target fishes. Notes: BL represents Black carp (Mylopharyngodon piceus), GR represents Grass carp (Ctenopharyngodon idella), SI represents silver carp (Hypophthalmichthysmolitrix), BI represents Bighead carp (Hypophthalmichthys nobilis). 
Table 2. The critical and burst swimming speed for different body lengths of test fish.

\begin{tabular}{|c|c|c|c|}
\hline Fish Species & Body Length of Fish & $\begin{array}{l}\text { Burst Swimming } \\
\text { Speed }(\mathrm{m} / \mathrm{s})\end{array}$ & $\begin{array}{c}\text { Relative Burst Swimming } \\
\text { Speed (BL/s) }\end{array}$ \\
\hline \multirow[t]{2}{*}{ BL } & $2-5 \mathrm{~cm}(n=16)$ & $0.42 \pm 0.33$ & $11.20 \pm 7.75$ \\
\hline & $5-8 \mathrm{~cm}(n=16)$ & $0.47 \pm 0.33$ & $7.09 \pm 4.85$ \\
\hline \multirow[t]{2}{*}{ GR } & $2-5 \mathrm{~cm}(n=16)$ & $0.27 \pm 0.20$ & $8.02 \pm 5.42$ \\
\hline & $5-8 \mathrm{~cm}(n=20)$ & $0.40 \pm 0.35$ & $6.14 \pm 5.12$ \\
\hline \multirow[t]{2}{*}{ SI } & $1-5 \mathrm{~cm}(n=17)$ & $0.23 \pm 0.21$ & $8.54 \pm 7.67$ \\
\hline & $5-9 \mathrm{~cm}(n=22)$ & $0.48 \pm 0.11$ & $7.13 \pm 2.36$ \\
\hline \multirow[t]{2}{*}{$\mathrm{BI}$} & $1-5 \mathrm{~cm}(n=21)$ & $0.33 \pm 0.21$ & $15.68 \pm 9.76$ \\
\hline & $5-9 \mathrm{~cm}(n=25)$ & $0.51 \pm 0.31$ & $7.10 \pm 4.26$ \\
\hline Fish Species & Body Length of Fish & $\begin{array}{l}\text { Burst Swimming } \\
\text { Speed }(\mathrm{m} / \mathrm{s})\end{array}$ & $\begin{array}{c}\text { Relative Burst Swimming } \\
\text { Speed (BL/s) }\end{array}$ \\
\hline \multirow[t]{2}{*}{ BL } & $2-5 \mathrm{~cm}(n=21)$ & $0.52 \pm 0.39$ & $16.37 \pm 8.47$ \\
\hline & $5-8 \mathrm{~cm}(n=20)$ & $0.57 \pm 0.48$ & $8.58 \pm 6.29$ \\
\hline \multirow[t]{2}{*}{ GR } & $2-5 \mathrm{~cm}(n=19)$ & $0.48 \pm 0.24$ & $14.03 \pm 7.45$ \\
\hline & $5-9 \mathrm{~cm}(n=17)$ & $0.76 \pm 0.39$ & $11.13 \pm 7.23$ \\
\hline \multirow[t]{2}{*}{ SI } & $1-5 \mathrm{~cm}(n=17)$ & $0.38 \pm 0.14$ & $11.87 \pm 3.51$ \\
\hline & $5-9 \mathrm{~cm}(n=15)$ & $0.69 \pm 0.44$ & $9.89 \pm 5.89$ \\
\hline \multirow[t]{2}{*}{$\mathrm{BI}$} & $1-5 \mathrm{~cm}(n=17)$ & $0.34 \pm 0.20$ & $13.23 \pm 8.24$ \\
\hline & $5-9 \mathrm{~cm}(n=29)$ & $0.69 \pm 0.44$ & $9.89 \pm 5.89$ \\
\hline
\end{tabular}

Table 3. Linear regression analysis for fish lengths.

\begin{tabular}{ccc}
\hline Speed Indexes & $\boldsymbol{U}_{\text {Crit }}$ & $\boldsymbol{U}_{\text {Crit }^{\prime}}$ \\
\hline BL & $\mathrm{R}^{2}=0.335, p<0.05$ & $\mathrm{R}^{2}=0.323, p<0.05$ \\
GR & $\mathrm{R}^{2}=0.325, p<0.05$ & $\mathrm{R}^{2}=0.350, p<0.05$ \\
SI & $\mathrm{R}^{2}=0.791, p<0.05$ & $\mathrm{R}^{2}=0.316, p<0.05$ \\
BI & $\mathrm{R}^{2}=0.461, p<0.05$ & $\mathrm{R}^{2}=0.421, p<0.05$ \\
\hline Speed Indexes & $\boldsymbol{U}_{\text {burst }}$ & $\boldsymbol{U}_{\text {burst }}$ \\
\hline BL & $\mathrm{R}^{2}=0.415, p<0.05$ & $\mathrm{R}^{2}=0.643, p<0.05$ \\
GR & $\mathrm{R}^{2}=0.543, p<0.05$ & $\mathrm{R}^{2}=0.382, p<0.05$ \\
SI & $\mathrm{R}^{2}=0.722, p<0.05$ & $\mathrm{R}^{2}=0.397, p<0.05$ \\
BI & $\mathrm{R}^{2}=0.603, p<0.05$ & $\mathrm{R}^{2}=0.63, p<0.05$
\end{tabular}

Notes: BL represents Black carp (Mylopharyngodon piceus), GR represents Grass carp (Ctenopharyngodon idella), SI represents silver carp (Hypophthalmichthys molitrix), BI represents Bighead carp (Hypophthalmichthys nobilis).

Table 4. One-way ANOVA analysis for two categories of length.

\begin{tabular}{ccccc}
\hline Speed Index & Fish Species & \multicolumn{2}{c}{ Two Categories Lengths of Fish } & $p$-Value \\
\hline \multirow{3}{*}{ Critical swimming } & BL & $2-5 \mathrm{~cm}(\mathrm{n}=16)$ & $5-8 \mathrm{~cm}(\mathrm{n}=16)$ & $p<0.05$ \\
speed for fish & GR & $2-5 \mathrm{~cm}(\mathrm{n}=16)$ & $5-8 \mathrm{~cm}(\mathrm{n}=20)$ & $p<0.05$ \\
& SI & $1-5 \mathrm{~cm}(\mathrm{n}=17)$ & $5-9 \mathrm{~cm}(\mathrm{n}=22)$ & $p<0.05$ \\
& BI & $1-5 \mathrm{~cm}(\mathrm{n}=21)$ & $5-9 \mathrm{~cm}(\mathrm{n}=25)$ & $p<0.05$ \\
\hline \multirow{3}{*}{ Burst swimming } & BL & $2-5 \mathrm{~cm}(\mathrm{n}=21)$ & $5-8 \mathrm{~cm}(\mathrm{n}=20)$ & $p<0.05$ \\
speed for fish & GR & $2-5 \mathrm{~cm}(\mathrm{n}=19)$ & $5-9 \mathrm{~cm}(\mathrm{n}=17)$ & $p<0.05$ \\
& SI & $1-5 \mathrm{~cm}(\mathrm{n}=17)$ & $5-9 \mathrm{~cm}(\mathrm{n}=15)$ & $p<0.05$ \\
& BI & $1-5 \mathrm{~cm}(\mathrm{n}=17)$ & $5-9 \mathrm{~cm}(\mathrm{n}=29)$ & $p<0.05$ \\
\hline
\end{tabular}

When plotted with dimension of body length (BL), the relatively critical swimming speed $U_{\text {crit }}{ }^{\prime}$ can be described as 4.26-17.10 BL/s for Black carp and 2.64-13.04 BL/s for grass carp. Similarly, the relatively critical swimming speed $U_{\text {crit }}{ }^{\prime}$ was ranging from 3.66 to 17.96 BL/s for silver carp and from 4.21 to $19.49 \mathrm{BL} / \mathrm{s}$ for bighead carp. The relationship between relative critical swimming speed, critical swimming speed, and fish length were indicated in Figure 3. Linear regression test on the relatively critical swimming speed 
of four carps with different lengths is shown in Table 3, and Kruskal-Wallis tests for the relative critical swimming speeds on different fish species is shown in Table 5.

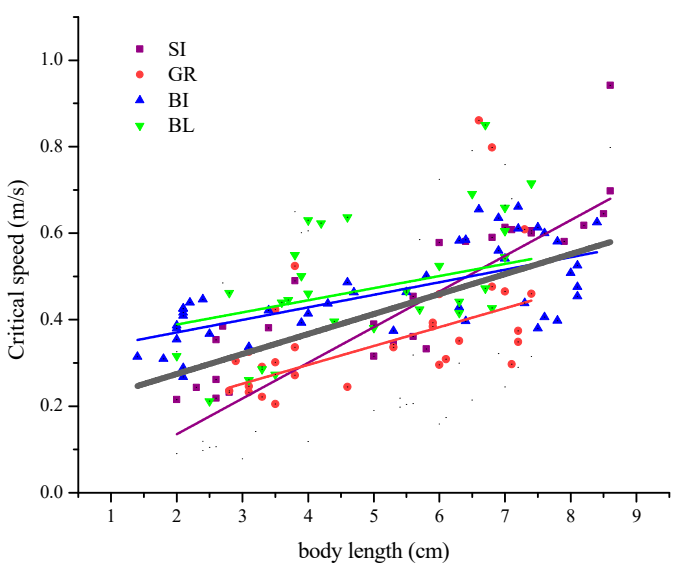

(a)

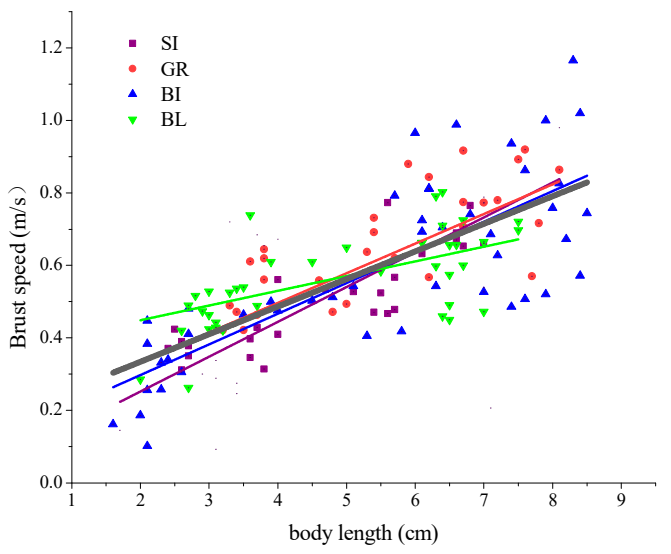

(c)

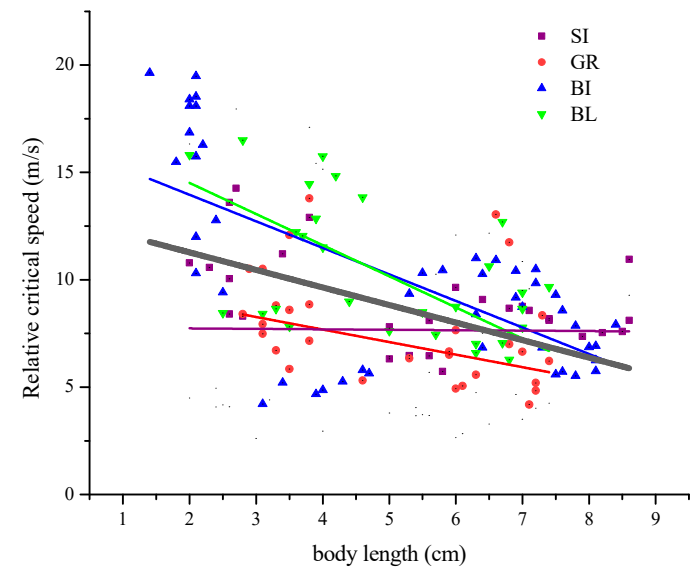

(b)

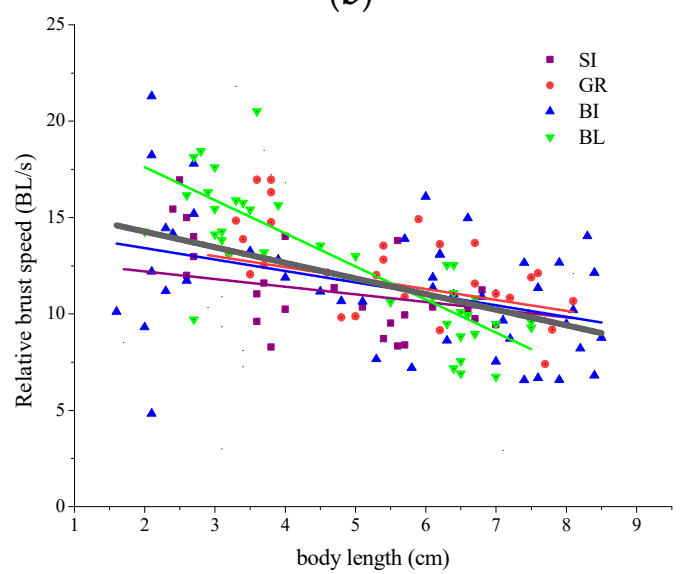

(d)

Figure 3. Linear regression of fish critical swimming speed $\left(U_{c r i t}\right)$, burst speed $\left(U_{\text {burst }}\right)$ for four carps that were tested. Regression lines for individual species are colored and regression lines for all species are black. Notes: BL represents Black carp (Mylopharyngodon piceus), GR represents Grass carp (Ctenopharyngodon idella), SI represents silver carp (Hypophthalmichthys molitrix), BI represents Bighead carp (Hypophthalmichthys nobilis).

Table 5. Kruskal-Wallis analysis for different fish species.

\begin{tabular}{ccc}
\hline Speed Index & Different Fish Species & $p$-Value \\
\hline & BI and SI & $p<0.05$ \\
Critical swimming speed & BL and GR & $p<0.05$ \\
& BI and BL & $p>0.05$ \\
& BI and GR & $p>0.05$ \\
SI and GR & $p>0.05$ \\
SI and BL & $p>0.05$ \\
\hline \multirow{3}{*}{ Burst swimming speed } & BI and SI & $p<0.05$ \\
& BL and GR & $p<0.05$ \\
& BI and BL & $p>0.05$ \\
& BI and GR & $p>0.05$ \\
& SI and GR & $p>0.05$ \\
\hline
\end{tabular}




\subsection{Burst Swimming Speed}

As shown in Figure 2, the burst swimming speeds were ranging from 0.11 to $1.05 \mathrm{~m} / \mathrm{s}$ for Black carp (2-8 cm), from 0.21 to $0.92 \mathrm{~m} / \mathrm{s}$ for Grass carp (2-9 cm), from 0.10 to $0.94 \mathrm{~m} / \mathrm{s}$ for Silver carp $(2-9 \mathrm{~cm})$, and from 0.29 to $1.16 \mathrm{~m} / \mathrm{s}$ for Bighead carp $(1-9 \mathrm{~cm})$, respectively. The burst swimming speed for different body lengths of test fish are shown in Table 2. Linear regression tests on the burst swimming speed of four carps with different lengths is shown in Table 3, and one-way ANOVA analysis for the burst swimming speed of the four carps at two categories of lengths $(1-5 \mathrm{~cm}, 5-9 \mathrm{~cm})$ is shown in Table 4 .

The relative burst swimming speed $U_{\text {burst }}{ }^{\prime}$ can be described as $1.50 \sim 14.0 \mathrm{BL} / \mathrm{s}$ for Black carp and 2.91 12.11 BL/s for Grass carp. Similarly, the relatively critical swimming speed $U_{\text {crit }}$ ' was ranging from 3.21 14.59 BL/s for Silver carp and from 4.69 to $14.04 \mathrm{BL} / \mathrm{s}$ for Bighead carp. The relationship between relative burst swimming speed, burst swimming speed, and fish length are indicated in Figure 3c,d. Linear regression tests on the relative burst swimming speed of four carps with different lengths is shown in Table 3, and KruskalWallis tests on the relative burst swimming speeds for different fish species is shown in Table 5.

Based on the experimental data of swimming speeds, the relationship between the critical swimming speed and the burst swimming speed of four carps with the body length range of $1.0 \sim 10.0 \mathrm{~cm}$ is as follows:

black carp: $U_{\text {burst }}=0.843 U_{\text {crit }}+18.205$

grass carp: $U_{\text {burst }}=1.618 U_{\text {crit }}+5.92$

silver carp: $U_{\text {burst }}=1.89 U_{\text {crit }}-1.67$

bighead carp: $U_{\text {burst }}=2.438 U_{\text {crit }}-50.686$

\section{Discussion}

\subsection{Relationship between Body Length and Swimming Capability}

The fish with different body lengths have different fish swimming abilities. Some studies have reported that they were the linear correlation between fish swimming speed and body length [16,20-22]. In this study, it can be seen from Figure 3 that the swimming speed (critical and burst swimming speed) $(\mathrm{m} / \mathrm{s})$ of the four carps increased with the increased body length, and the relative (critical and burst) swimming speed (BL/s) decreases with body length, which is similar to previous research results. Additionally, it showed that the burst swimming speed of the four carps at two categories of lengths $(1-5 \mathrm{~cm}, 5-9 \mathrm{~cm})$ was significantly different $(p<0.05)$ (Table 4$)$, and the critical swimming speed of four carps at two categories of lengths was significantly different $(p<0.05)$. This revealed from another perspective that the swimming ability of fish is greatly related to the body length of fish.

In this study, the $U_{\text {crit }}$ of four carps (body length $1-9 \mathrm{~m}$ ) was $0.10-0.94 \mathrm{~m} / \mathrm{s}$ (2.64-19.49 BL/s). Compared with four carps of other body lengths reported (in Table 6), the critical swimming speed was higher for the longer fish. This may be that the relative values of fish surface area and muscle weight scales increased in proportion with the increased fish size, and the propulsion power of fish overcoming the body weight is inversely proportionate to the size of body length $[15,23,24]$.

\subsection{Comparison of Swimming Capability of Four Carps}

The $U_{\text {crit }}$ represents the maximum sustained swimming ability of fish. The critical swimming speed of different fishes can be used to evaluate the ecological environment of fish habitat [25]. In this study, the critical swimming speed was different with different fish species. Compared with the critical swimming speed of different fish species, the bighead carp and silver carp showed significant difference $(p<0.05)$ (Table 5), and there was significant difference between black carp and grass carp $(p<0.05)$ (Table 5). However, there is no significant difference $(p>0.05)$ except for the above two groups. It may be due to the fish habits, habitat environment, morphological characteristics of fish, which result in significant differences on fish swimming ability [5]. For example, black carp habitat in the bottom water, and the activity of grass carp are near the bank of river. Although silver 
carp and bighead carp habitat in the upper water, silver carp like jumping and bighead carp are inactive.

The burst swimming speed is a measure of sprint speed responding to the survival of fish, such as predators, escapes, etc. [26]. Compared with the burst swimming speed of different fish species, the significant difference between black carp and silver carp was shown $(p<0.05)$ (Table 5). Additionally, it showed a significant difference in burst swimming speed between grass carp and silver carp $(p<0.05)$ (Table 5). These were similar to the research results of Xiong et al. (2014) [27]. It may be related to fish behavior that silver carp likes jumping, while the grass carp is relatively active and black carp is timid and slow to move [28].

Table 6. Burst and critical swimming speeds of the four carps.

\begin{tabular}{|c|c|c|c|c|c|c|c|}
\hline $\begin{array}{c}\text { Fish } \\
\text { Species }\end{array}$ & $\begin{array}{c}\text { Temperature } \\
\left({ }^{\circ} \mathrm{C}\right)\end{array}$ & $\begin{array}{l}\text { Body Length } \\
\text { (cm) }\end{array}$ & $U_{c r i t}{ }^{\prime}(\mathrm{BL} / \mathrm{s})$ & $U_{\text {crit }}(\mathrm{m} / \mathrm{s})$ & $U_{\text {burst }}{ }^{\prime}(\mathrm{BL} / \mathrm{s})$ & $U_{\text {burst }}(\mathrm{m} / \mathrm{s})$ & References \\
\hline \multirow{4}{*}{$\mathrm{BL}$} & $25 \pm 1$ & $6.81 \pm 0.05$ & / & $0.45 \pm 0.05$ & / & / & [29] \\
\hline & $23 \pm 0.8$ & $6.80 \pm 1.04$ & $9.14 \pm 4.82$ & $0.44 \pm 0.22$ & / & / & In our study \\
\hline & $21 \pm 2$ & $19.0 \pm 6.09$ & / & / & $5.67 \pm 1.22$ & / & [27] \\
\hline & $23 \pm 0.8$ & $6.63 \pm 1.12$ & / & / & $8.46 \pm 2.13$ & $0.59 \pm 0.14$ & In our study \\
\hline \multirow{5}{*}{ GR } & $28 \pm 1$ & $9.8 \pm 0.80$ & $8.88 \pm 0.50$ & $0.87 \pm 0.10$ & / & 1 & [11] \\
\hline & $28 \pm 1$ & $12.3 \pm 0.80$ & $7.71 \pm 0.82$ & $0.95 \pm 0.05$ & / & / & [11] \\
\hline & $23 \pm 0.8$ & $6.52 \pm 1.17$ & $6.97 \pm 2.83$ & $0.34 \pm 0.16$ & / & / & In our study \\
\hline & $21+2$ & $21.57 \pm 6.10$ & / & / & $5.98 \pm 1.14$ & / & [27] \\
\hline & $23 \pm 0.8$ & $7.23 \pm 1.05$ & / & / & $10.79 \pm 2.24$ & $0.71 \pm 0.07$ & In our study \\
\hline \multirow{7}{*}{ SI } & $20 \pm 1$ & $10.11 \pm 0.24$ & $6.45 \pm 0.27$ & $0.66 \pm 0.02$ & / & / & [28] \\
\hline & $20 \pm 1$ & $16.90 \pm 0.55$ & $4.97 \pm 0.14$ & $0.84 \pm 0.03$ & / & / & [28] \\
\hline & $30 \pm 1$ & $10.09 \pm 0.53$ & $6.69 \pm 0.11$ & $0.67 \pm 0.03$ & / & / & [13] \\
\hline & $30 \pm 1$ & $11.84 \pm 0.67$ & $6.45 \pm 0.08$ & $0.76 \pm 0.03$ & / & / & [13] \\
\hline & $23 \pm 0.8$ & $6.98 \pm 1.06$ & $10.49 \pm 5.98$ & $0.38 \pm 0.14$ & / & / & In our study \\
\hline & $21 \pm 2$ & $20.70 \pm 7.63$ & / & / & $6.60 \pm 1.62$ & / & [27] \\
\hline & $23 \pm 0.8$ & $7.36 \pm 1.12$ & / & / & $11.07 \pm 1.16$ & $0.73 \pm 0.06$ & In our study \\
\hline \multirow{6}{*}{ BI } & $20 \pm 1$ & $10.78 \pm 1.34$ & $7.57 \pm 0.62$ & $0.81 \pm 0.04$ & / & / & [28] \\
\hline & $20 \pm 1$ & $15.39 \pm 0.62$ & $5.66 \pm 0.23$ & $0.87 \pm 0.03$ & / & / & [28] \\
\hline & $20 \pm 1$ & $19.99 \pm 1.58$ & $4.60 \pm 3.54$ & $0.92 \pm 0.04$ & / & / & [28] \\
\hline & $23 \pm 0.8$ & $7.51 \pm 1.14$ & $10.49 \pm 5.98$ & $0.38 \pm 0.14$ & / & / & In our study \\
\hline & $21 \pm 2$ & $21.29 \pm 7.01$ & / & / & $5.05 \pm 9.04$ & / & [27] \\
\hline & $23 \pm 0.8$ & $7.52 \pm 0.91$ & / & / & $9.91 \pm 1.76$ & $0.65 \pm 0.11$ & In our study \\
\hline
\end{tabular}

The swimming capability was tested in a controlled swim chamber, which produced a more uniform water flow than that encountered in typical streams and rivers. Thus, that means that the above laboratory-derived data are likely to produce conservative estimates of maximal allowable water velocity [28,30]. It was noted that fish swimming ability measured in a flume chamber may be slightly lower than in natural water. Thus, future study should focus on how hydraulic associated with fish behavior in fishway designs in open-channel flume or natural water.

\subsection{The Relationship between Critical Swimming Speed and Burst Swimming Speed}

Critical swimming speed is an important indicator of aerobic exercise; it represents the maximum sustained swimming ability of fish, while burst swimming speed is an evaluation indicator of anaerobic swimming ability of fish [9]. Thus, the relationship between the critical swimming speed and burst swimming speed is aerobic exercise and anaerobic exercise.

The studies on the relationship between the aerobic exercise ability and anaerobic exercise ability of fish mainly considered the critical swimming speed and burst swimming speed as measurement indexes, so as to analyze the tradeoff between exercise ability. Ojanguren and Brana (2003) [31] compared the relationship between maximum swimming 
speed and tolerance time of brown trout (Salmo trutta L.) juveniles, and the results showed a negative correlation. In addition, there was a negative correlation between the critical swimming speed and the burst swimming speed on Gadus morhua L., which is expressed as $U_{\text {crit }}=105.83-0.446 U_{\text {burst }}$. Thus, it indicated that there was a trade-off between the aerobic and anaerobic exercise capacity of fish [32]. Yan et al. (2012) [33] found that the aerobic exercise capacity and anaerobic exercise capacity of 6 fish species also had a tradeoff effect at different temperatures. Based on the video observation of swimming behavior in the chamber during tests, there existed gait transitions and strategies employed by four carp species. The phenomenon may be explained by anaerobic metabolism and aerobic metabolism working together quickly, resulting in fatigue [14,23].

Additionally, the fish swimming ability refers to the combined effects of physiological factors (such as fish motor muscle, oxygen consumption rate, etc.) and environmental factors (such as habitat, water, etc.) [34,35]. The difference in swimming speed of carp species with different body length groups needs to be further explored from the perspective of fish physiology, and the swimming speeds are greatly affected by temperature $[9,36]$. In this study, the experimental temperature fluctuated between $19{ }^{\circ} \mathrm{C}$ and $25{ }^{\circ} \mathrm{C}$, which may have effects on the swimming ability. Further work should be studied on the effects of temperature on swimming ability for small body length of four carps.

\subsection{Applications for Fish Passage}

Effective facilities were being designed and will be built in the Yangtze River that allowed fish passage up- and down-river. The design of the passage system integrated both physical (hydrology, hydraulics, habitat, etc.) and biological (fish swimming performance) factors $[21,22]$. Differences in swimming performances can help fish adapt to their surrounding water flow regimes. Thus, the data on fish swimming performance can provide useful information for the design criteria of fish passage facilities or habitat reconstruction, and fish may employ a series of swimming strategies when crossing hydraulic barriers [26]. Factually, water velocities in fish passage should be less than the fish burst swimming speed [14]. Specifically, if many species use a fish passage, water velocities must be maintained within the swimming performance of all species. Thus, the fish passage for four carps should have a flow velocity suitable for all the species.

In addition, we have changed the fish body length to obtain different fish swimming abilities. That means that the above laboratory-derived data are likely to produce conservative estimates of maximal allowable water velocities [29], although it was noted that fish swimming ability measured in a flume chamber may be slightly lower than in natural water. Future study is required to understand how hydraulic is associated with fish behavior in open-channel flume or natural water.

\section{Conclusions}

The swimming performances of four carps (black carp, grass carp, silver carp, and bighead carp) with smaller body lengths $(1.0-9.0 \mathrm{~cm})$ in a swimming flume were evaluated. The critical and burst swimming speed $(\mathrm{m} / \mathrm{s})$ of the four carps increased with the increased length, and the relative (critical and burst) swimming speed (BL/s) decreases with length. The critical and burst swimming speed of each species at two individual length groups $(1.0-5.0 \mathrm{~cm}, 5.1-9.0 \mathrm{~cm})$ was significantly different $(p<0.05)$. Compared with the burst swimming speed of different fish species, the significant difference between black carp and silver carp, grass carp and silver carp were shown $(p<0.05)$. Additionally, the significant difference between bighead carp and silver carp, black carp and grass carp were shown with the critical swimming speed of different fish species $(p<0.05)$. In summary, the investigation of fish swimming performances can provide valuable data for engineers and biologists for the construction of fish passage and the restoration of ecological habitat. 
Author Contributions: All authors listed have contributed substantially to the manuscript to be included as authors. Conceptualization: J.T., H.L., W.G., and X.S.; data curation: H.L., W.G., H.T., S.K., J.W., and X.S.; formal analysis: J.T.; funding acquisition: J.T.; investigation: H.T. and J.W.; methodology: H.T. and X.S.; project administration: J.T. and H.L.; software, S.K.; visualization: J.W.; writing-original draft: J.T., W.G., S.K., and X.S. All authors have read and agreed to the published version of the manuscript.

Funding: This study was funded by the Hubei Key Laboratory of Three Gorges Project for Conservation of Fishes (SXSN/4507), National Natural Science Foundation of China (51709152, 51579136), and Hubei International Science and Technology Cooperation Base of Fish Passage (HIBF2020007).

Institutional Review Board Statement: Not applicable.

Informed Consent Statement: Not applicable.

Data Availability Statement: Not applicable.

Acknowledgments: Thanks to Chen Lei for technical support during the experiment period.

Conflicts of Interest: The authors declare no conflict of interest.

\section{References}

1. Tan, J.; Gao, Z.; Dai, H.; Shi, X. Effects of turbulence and velocity on the movement behaviour of bighead carp (Hypophthalmichthys nobilis) in an experimental vertical slot fishway. Ecol. Eng. 2019, 127, 363-374. [CrossRef]

2. Newbold, L.R.; Shi, X.; Hou, Y.; Han, D.; Kemp, P.S. Swimming performance and behaviour of bighead carp (Hypophthalmichthys nobilis): Application to fish passage and exclusion criteria. Ecol. Eng. 2016, 95, 690-698. [CrossRef]

3. Hu, M.; Hua, Q.; Zhou, H.; Wu, Z.; Wu, X. The effect of dams on the larval abundance and composition of four carp species in key river systems in China. Environ. Biol. Fishes 2015, 98, 1201-1205. [CrossRef]

4. Katopodis, C.; Williams, J.G. The development of fish passage research in a historical context. Ecol. Eng. 2012, 48, 8-18. [CrossRef]

5. Silva, A.T.; Lucas, M.C.; Castro-Santos, T.; Katopodis, C.; Baumgartner, L.J.; Thiem, J.D.; Cooke, S.J. The future of fish passage science, engineering, and practice. Fish Fish. 2018, 19, 340-362. [CrossRef]

6. Li, M.; Shi, X.; Jin, Z.; Ke, S.; Lin, C.; An, R.; Li, J.; Katopodis, C. Behaviour and ability of a cyprinid (Schizopygopsis younghusbandi) to cope with accelerating flows when migrating downstream. River Res. Appl. 2020, 1-12. [CrossRef]

7. Brett, J. The respiratory metabolism and swimming performance of young sockeye salmon. Can. J. Fish Aquat. Sci. 1964, 21, 1183-1226. [CrossRef]

8. $\quad$ Eliason, E.J.; Clark, T.D.; Hague, M.J.; Hanson, L.M.; Gallagher, Z.S.; Jeffries, K.M.; Gale, M.K.; Patterson, G.A.; Hinch, S.G.; Farrell, A.P. Differences in thermal tolerance among sockeye salmon populations. Science 2011, 332, 109-112. [CrossRef]

9. Cano-Barbacil, C.; Radinger, J.; Argudo, M.; Rubio-Gracia, F.; Vila-Gispert, A.; García-Berthou, E. Key factors explaining critical swimming speed in freshwater fish: A review and statistical analysis for Iberian species. Sci. Rep. 2020, 10, 18947. [CrossRef]

10. Cai, L.; Fang, M.; Tu, Z.; Liu, G.; Shi, X.; Huang, Y. Research progress on fish swimming characteristics related to fish migration. J. Wuhan Univ. 2013, 59, 363-368.

11. Gong, L.; Wu, Y.; Bai, Y.; Mu, X. Experimental study on swimming ability and swimming behavior of juvenile grass carp. J. Chin. Inst. Water Resour. Hydropower Res. 2015, 13, 211-216. [CrossRef]

12. Hou, Y.; Newbold, L.; Cai, L.; Wang, X.; Hu, W.; Qiao, Y. Swimming performance of juvenile Aristichthys nobilis under fixed velocity swimming tests. Chin. J. Ecol. 2016, 35, 1583-1588. [CrossRef]

13. Li, H.; Cai, D.; Yang, P. Swimming ability and behavior of different sized silver carp. J. Hydroecol. 2016, 37, 88-92. [CrossRef]

14. Peake, S.J.; Beamish, F.W.; McKinley, R.S.; Scruton, D.A.; Katopodis, C. Relating swimming performance of lake sturgeon, Acipenser fulvescens, to fishway desing. Can. J. Fish Aquat. Sci. 1997, 54, 1361-1366. [CrossRef]

15. Deslauriers, D.; Kieffer, J.D. The influence of flume length and group size on swimming performance in shortnose sturgeon Acipenser brevirostrum. J. Fish Biol. 2011, 79, 1146-1155. [CrossRef] [PubMed]

16. Hou, Y.; Cai, L.; Wang, X.; Chen, X.; Zhu, D.; Johnson, D.; Shi, X. Swimming performance of 12 Schizothoracinae species from five rivers. J. Fish Biol. 2018, 92, 2022-2028. [CrossRef]

17. Castro, M.A.; Santos, H.A.; Sampalo, A.C.; Pompeu, P.S. Swimming performance of the small characin Bryconamericus stramineus (Characiformes: Characidae). Zoologia 2010, 27, 939-944. [CrossRef]

18. Smit, H.; Amelink-Kouutsataal, J.M.; Vijverberg, J.; von Vaupel-Klein, J.C. Oxygen consumption and efficiency of swimming goldfish. Comp. Biochem. Physiol. 1971, 39, 1-28. [CrossRef]

19. Laborde, A.; González, A.; Sanhueza, C.; Arriagada, P.; Wilkes, M.; Habit, E.; Link, O. Hydropower Development, Riverine Connectivity, and Non-sport Fish Species: Criteria for Hydraulic Design of Fishways. River Res. Appl. 2016, 32, 1949-1957. [CrossRef]

20. Poletto, J.B.; Cocherell, D.E.; Ho, N.; Cech, J.J.J.; Klimley, A.P.; Fangue, N.A. The effect of size on juvenile green sturgeon (Acipenser medirostris) behavior near water-diversion fish screens. Environ. Biol. Fish 2018, 101, 67-77. [CrossRef]

21. Cai, L.; Katopodis, C.; Johnson, D.; Zhang, P.; Zhao, P. Case study: Targeting species and applying swimming performance data to fish lift design for the Huangdeng Dam on the upper Mekong River. Ecol. Eng. 2018, 122, 32-38. [CrossRef] 
22. Cooke, S.J.; Cech, J.J.; Glassman, D.M.; Simard, J.; Louttit, S.; Lennox, R.J.; Cruz-Font, L.; O'Connor, C.M. Water resource development and sturgeon (Acipenseridae): State of the science and research gaps related to fish passage, entrainment, impingement and behavioural guidance. Rev. Fish Biol. Fish. 2020, 30, 7755. [CrossRef]

23. Hammer, C. Fatigue and exercise tests with fish. Comp. Biochem. Physiol. Part A Physiol. 1995, 112, 1-20. [CrossRef]

24. Cai, L.; Hou, Y.; Katopodis, C.; He, D.; Johnson, D.M.; Zhang, P. Rheotaxis and swimming performance of Perch-barbel (Percocypris pingi, Tchang, 1930) and application to design of fishway entrances. Ecol. Eng. 2019, 132, 102-108. [CrossRef]

25. Farrell, A.P. Comparisons of swimming performance in rainbow trout using constant acceleration and critical swimming speed tests. J. Fish Biol. 2008, 72, 693-710. [CrossRef]

26. Plaut, I. Critical swimming speed: Its ecological relevance. Comp. Biochem. Physiol. Part A Mol. Integr. Physiol. 2001, 131, 41-50. [CrossRef]

27. Xiong, F.; Wang, C.; Liu, D.; Mo, W.; Liu, W.; Shi, X. Comparative study of burst swimming speed of black carp, grass carp, silver carp and bighead carp from Songhua River. Ecol. Sci. 2014, 33, 339-343.

28. Liu, H.; Wang, C.; Zhu, L.; Chen, M. Comparative study of critical swimming speed for juvenile silver and bighead carp. J. Hydroecol. 2016, 37, 63-69.

29. Fu, X.; Fu, C.; Fu, S. Comparison of swimming ability among five freshwater fish species. Chin. J. Ecol. 2020, 39, 1629-1635. [CrossRef]

30. Kern, P.; Cramp, R.L.; Gordos, M.A.; Waston, J.R.; Franklin, C.E. Measuring Ucrit and endurance: Equipment choice influences estimates of fish swimming performance. J. Fish Biol. 2018, 92, 237-247. [CrossRef]

31. Ojanguren, A.F.; Brana, F. Effects of size and morphology on swimming performance in juvenile brown trout (Salmo trutta L). Ecol. Freshw. Fish 2003, 12, 241-246. [CrossRef]

32. Norin, T.; Clark, T.D. Measurement and relevance of maximum metabolic rate in fishes. J. Fish Biol. 2016, 88, 122-151. [CrossRef] [PubMed]

33. Yan, G.; He, X.; Cao, Z.; Fu, S. The trade-off between steady and unsteady swimming performance in six cyprinids at two temperatures. J. Therm. Biol. 2012, 37, 424-431. [CrossRef]

34. Losos, J.B.; Walton, B.M.; Bennett, A.F. Trade-offs between sprinting and clinging ability in Kenyan chameleons. Funct. Ecol. 1993, 7, 281-286. [CrossRef]

35. Langerhans, R.B. Trade-off between steady and unsteady swimming underlies predator-driven divergence in Gambusiaaffinis. J. Evol. Biol. 2009, 22, 1057-1075. [CrossRef] [PubMed]

36. Lyon, J.P.; Ryan, T.J.; Scroggie, M.P. Effects of temperature on the fast-start swimming performance of an Australian freshwater fish. Ecol. Freshw. Fish 2008, 17, 184-188. [CrossRef] 